\title{
ІНСТИТУТ ЗАРЕССТРОВАНОГО ПАРТНЕРСТВА \\ ТА ФАКТИЧНІ ШЛЮБНІ ВІДНОСИНИ В УКРӒ̈НІ І КРАЇНАХ-ЧЛЕНАХ ЄС: ПОНЯТТЯ Й ОСОБЛИВОСТІ
}

Булеца С. Б., Ревуцька I. Е.

\section{ВСТУП}

Із посиленням євроінтеграційних процесів проблема визнання шлюбними або сімейними відносин, заснованих на різних, відмінних від шлюбу, підставах, набула особливої актуальності. Визначаючи три основні напрями, що вимагають особливої уваги з позиції гармонізації законодавства $\mathrm{CC}$, К. Боле-Волкі вказує як на один з них на створення європейської моделі сімейного союзу не на підставі шлюбу (перші два - це питання, пов'язані з правом на розірвання шлюбу та надання утримання, а також блок питань, що стосуються батьківських обов'язків) ${ }^{1}$.

Слід зазначити, що часто вибір підстав, на яких буде створено сім’ю, форми організації відносин пари залежить від національного законодавства. В одних випадках воно може бути «дискримінаційним» стосовно осіб, які перебувають у законному шлюбі, в інших випадках - навпаки. Так, шлюб може бути вигідним або невигідним з точки зору оподаткування, формально одинокі батьки можуть отримувати певні пільги тощо. Таким чином, інші галузі права, зокрема податкове, трудове, право соціального забезпечення, можуть завдавати впливу на вибір партнерами підстав створення сім'ї і, відповідно, її виду.

Незважаючи на визнаний консервативний характер правового регулювання сімейних відносин, особливо в частині, що стосується шлюбу, нині ми спостерігаємо процеси досить активної трансформації традиційної сім’ї і, відповідно, підходів до питання, що саме слід вважати підставами іiі створення. У юридичній літературі все частіше стають предметом обговорення різновиди так званої «альтернативної поведінки в шлюбно-сімейних відносинах», до яких зазвичай відносять повторні, відкриті та інші види шлюбів². Слід одразу зазначити, що не всі види такої альтернативної поведінки підлягають правовому регулюванню. Зокрема, відкритий або гостьовий шлюб є предметом

\footnotetext{
1 Boele-Woelki K. The principles of European family law: its aims and prospects. Utrecht Law Review. 2005. Volume 1, Issue 2 (December). P. 163.

2 Кац М.Н. Формы современной украинской семьи: аксиологический аспект. Вісник СевНТУ : збірник наукових праць. 2012. Випуск 126. С. 55.
} 
вивчення скоріше соціології або психології. 3 позиції юриспруденції частіше за все йдеться про проживання однією сім'єю жінки та чоловіка без реєстрації шлюбу.

Мета дослідження - дати визначення зареєстрованого партнерства та фактичних шлюбних відносин, розкрити бачення авторів на можливість запровадження цих явищ на практиці, а також зробити порівняння з країнами-членами СС.

\section{1. Інститут заресстрованого партнерства як правова підстава створення сім'ї у країнах-членах ЄС та перспектива його запровадження в Україні}

Інститут зареєстрованого партнерства є одним із поширених у країнах-членах СС правових інститутів, пов'язаних із сімейним правом. Він був запроваджений та закріплений на законодавчому рівні в окремих європейських країнах наприкінці минулого століття як відповідь на поширення в суспільстві сімейних відносин між чоловіками та жінками без офіційного укладення шлюбу, а також між особами однієї статі, які тоді в принципі не могли укласти шлюб або легалізувати свої стосунки будь-яким іншим способом. Слід зауважити, що стосовно останньої категорії інститут зареєстрованого партнерства дав змогу державам забезпечити компроміс між неготовністю суспільства до сприйняття одностатевих шлюбів та необхідністю забезпечити права осіб однієї статі, не пов'язаних спорідненням, які перебували у фактично сімейних відносинах.

Розглядаючи причини, що змусили уряди різних країн порушити питання про запровадження інституту зареєстрованого партнерства до регулювання відносин одностатевих пар, слід також звернути увагу на їх зв'язок із таким глобальним питанням XX століття, як права людини. Історичні події першої половини минулого століття змусили людство по-іншому подивитися на права людини. Особливо це стосувалося європейського континенту, населення якого найбільшою мірою постраждало внаслідок світових війн. Перелік прав людини поступово розширювався і нині у ньому виділяється група статевих прав, які входять до соматичних прав людини.

За визначенням Всесвітньої організації охорони здоров'я, статеві права полягають у можливості шукати, отримувати і передавати інформацію, що стосується статевих питань, статевої освіти; вибору партнера; можливості вирішувати питання про власну сексуальну активність; добровільності сексуальних контактів; 
можливості укладати шлюб тощо. Слід зазначити, що більшість справ, порушених у Європейському суді з прав людини протягом останніх двадцяти років стосовно прав сексуальних меншин, вирішувалась на користь позивачів.

Таким чином, інститут зареєстрованого партнерства має розглядатися насамперед у контексті прав людини і не $\epsilon$ суто сімейно-правовим інститутом. Водночас у цьому дослідженні його розгляд $\epsilon$ доцільним і навіть необхідним, оскільки зареєстроване партнерство є однією 3 поширених у країнах-членах $\mathrm{CC} \mathrm{підстав} \mathrm{створення} \mathrm{сім'ї3.}$

У цьому контексті слід зазначити, що в юридичній літературі звертається увага на те, що поширення норм про права людини на регулювання сімейних відносин загалом притаманне сучасному європейському праву. Так, розглядаючи питання адаптації сімейного права України до стандартів європейського правового простору, О.А. Явор указує: «Однією з головних тенденцій нині західні вчені називають усе більше розгортання дії норм у галузі прав людини на регулювання відносин у сім'ї. Це великою мірою пов'язано із загальним зростанням значення стандартів у галузі прав людини та їх усвідомленням загалом у політиці й праві. Варто визнати: права людини посідають безпрецедентне місце в політичному і правовому дискурсі сьогодення. Концепція сім'ї та сімейного права не могла залишитися поза такими загальними тенденціями. Зміни у регулюванні сімейних відносин, які відбуваються на сучасному етапі розвитку, підкреслюють посилення загального принципу поваги до людини, до її потреб і бажань, поряд із повагою до таких груп, як «сім'я» або навіть «суспільство» загалом. Таким чином, можна говорити про загальноєвропейську тенденцію руху від «сім’ї» до «індивіда»

Другий момент, на якому слід зосередити увагу, полягає у тому, що хоча зареєстроване партнерство $з$ позиції сімейного права слід розглядати саме як підставу створення сім’і, проте його не можна прирівнювати до шлюбу або фактичних шлюбних відносин. Мета інституту зареєстрованого партнерства полягає насамперед у врегулюванні майнових та спадкових відносин його сторін, а також вирішенні проблем, що виникають у сфері податкових відносин та

\footnotetext{
3 Ревуцкая И.Э. Зарегистрированное партнерство как основание создания семьи в законодательстве стран-членов Европейского Союза. Журнал "Legea si Viata” Respublica Moldova. 2017. № 9 (309). С. 103.

4 Явор О.А. Адаптація сімейного права України до стандартів європейського правового простору: значення для теорії юридичних фактів. Науковий вісник Ужгородського наи. ун-ту. Серія «Право». 2015. Випуск 4, т. 1. С. 134.
} 
пенсійного забезпечення. Хоча іноді в юридичній літературі зареєстроване партнерство називають проміжною формою відносин між шлюбом та фактичним спільним проживанням ${ }^{5}$. Водночас іноді цивільне партнерство вважається таким, що може порівнюватись, або навіть еквівалентним шлюбу. Так, наприклад, у юридичній літературі зазначалося: «1 жовтня 1989 року Данія стала першою країною в сучасній західноєвропейській цивілізації, яка легально визнала одностатеві шлюби, надавши їм офіційну назву «зареєстроване партнерство». Це смілива частина данського законодавства. Акт про зареєстровані партнерства являє собою значну віху в прогресі прав людини» 6 .

Слід також зазначити, що нині країни-члени ЄС фактично поділились на дві групи залежно від того, чи дозволяються в них одностатеві шлюби. Відповідно, у країнах, де дозволений одностатевий шлюб, визнаються і одностатеві партнерства, укладені в інших країнах. У країнах, де одностатевий шлюб не визнається, у разі його укладення за кордоном подружжю на території такої країни надаються такі самі права, які надаються зареєстрованим одностатевим партнерам

Нині можливість зареєстрованого партнерства для одностатевих пар передбачена законодавством багатьох країн-членів $\mathrm{CC}$, серед яких - Австрія, Греція, Данія, Естонія, Італія, Кіпр, Німеччина, Угорщина, Хорватія, Чехія та ін. Інститут зареєстрованого партнерства ще не було запроваджено Болгарією, Латвією, Литвою, Польщею, Румунією та Словаччиною.

У країнах-членах ЄС відносини щодо зареєстрованого партнерства зазвичай регулюються спеціальним законодавством, особливо коли йдеться саме про одностатеві пари. Водночас окремі аспекти зареєстрованого партнерства можуть встановлюватись цивільним і сімейним законодавством. Зокрема, до зареєстрованого партнерства можуть застосовуватись деякі положення сімейного законодавства, що стосуються умов укладення шлюбу. Так, наприклад, за законодавством Данії (The Registered Partnership Act, 1999) ${ }^{8}$ до зареєстрованого

5 Дородонова Н.В. Современные тенденции развития форм совместного проживания (на примере Бельгии). Вопросы российского и международного права. 2011. № 2. C. 116. URL: http://publishing-vak.ru/file/archive-law-2011-2/9-dorodonova.pdf (дата звернення: 15.12.2019).

6 Martin J. English Polygamy Law and the Danish Registered Partnership Act: A Case for the Consistent Treatment of Foreign Polygamous Marriages and Danish Same-Sex Marriages in England. Cornell International Law Journal. 1994. Volume 27. Issue 2. P. 419.

Civil unions and registered partnerships. URL: http://europa.eu/youreurope/citizens/family/ couple/registered-partners/index_en.htm (дата звернення: 15.12.2019).

8 The Registered Partnership Act of Denmark (D/341- H- ML Act No. 372 of June 1, 1989). URL: http://www.inakost.sk/clanky_foto/file/Dansko.pdf (дата звернення: 15.12.2019). 
партнерства застосовуються такі положення, встановлені шлюбним законодавством (The Formation and Dissolution Marriage Act $^{9}$ ), як загальні положення щодо укладення шлюбу: шлюбний вік встановлюється у 18 років, а для його укладення до досягнення шлюбного віку необхідно отримати дозвіл канцелярії губернатора графства. Крім того, у разі укладення шлюбу особою віком до 18 років, яка раніше не перебувала у шлюбі, необхідна згода батьків на укладення нею шлюбу. Не допускається укладення шлюбу між родичами прямої лінії споріднення, братами та сестрами, усиновлювачем та усиновленим, між особами, з яких хоча б одна перебуває в іншому шлюбі або зареєстрованому партнерстві. Крім того, процедура реєстрації шлюбу передбачає присутність обох партнерів. До зареєстрованого партнерства, за деякими винятками, застосовуються і правові наслідки шлюбу. Слід відзначити, що останні зміни, що було внесено до національного сімейного законодавства Данії, набрали чинності 1 лютого 2017 року і передбачають, що шлюб або зареєстроване партнерство, укладені за межами Данії, не можуть бути визнані у разі:

- якщо хоча б один з партнерів на момент реєстрації шлюбу або зареєстрованого партнерства не досяг 18-річного віку;

- якщо один з партнерів був відсутній під час реєстрації.

Загалом зміни до законодавства було спрямовано на перешкоджання спробам обходу положення національного законодавства щодо мінімального шлюбного віку ${ }^{10}$.

Для одностатевого партнерства можуть встановлюватись винятки iз загальних положень про шлюб. Так, наприклад, в Угорщині можливість зареєстрованого партнерства для осіб однієї статі існує з 2009 року, коли набрав чинності Закон про зареєстровані партнерства, прийнятий у 2007 році. На відміну від шлюбу, укладення якого з дозволу батьків можливе особами, які досягли віку 16 років, зареєстроване партнерство можливе лише між повнолітніми особами. Що стосується майнових наслідків шлюбу, а також спадкових відносин, то наслідки зареєстрованого партнерства прирівнюються до наслідків шлюбу.

Аналіз законодавства деяких країн-членів СС дає можливість визначити спільні риси у правовому регулюванні зареєстрованого партнерства стосовно одностатевих пар.

\footnotetext{
9 Schanda B. A jog lehetõségei a család védelmére. URL: http://ias.jak.ppke.hu/hir/ ias/20122sz/09.pdf (дата звернення: 15.12.2019) .

10 Validity of marriage or registered partnership. URL: https://www.nyidanmark.dk/en-us/ coming_to_dk/work/Accompanying - family/Validity_marriage.htm (дата звернення: 15.12.2019). 
Так, порівняно зі шлюбом зареєстроване партнерство може містити обмеження стосовно права обирати спільне ім'я, права усиновлювати дитину або звертатися до допоміжних репродуктивних технологій, презумпції батьківства. Можуть також встановлюватись обмеження стосовно можливості зареєстрованого партнерства залежно від місця постійного проживання або громадянства партнерів.

Наприклад, актом про зареєстроване партнерство Данії ${ }^{11}$ як обов'язкова умова реєстрації партнерства двох осіб однієї статі висувається умова, щоб обидва або хоча б один із партнерів мав місце постійного проживання в Данії та був данчанином.

Законодавство Швеції, регулюючи зареєстроване партнерство саме для одностатевих пар, встановлює, що необхідно, щоб принаймні один із партнерів був громадянином Швеції або мав постійний вид на проживання у Швеції.

Такий вид партнерства, як довічне партнерство, до останнього часу містився у праві ФРН. Інститут довічного партнерства був запроваджений Законом про довічне партнерство від 16 лютого 2001 року і дав змогу юридично оформити сімейний союз, що створювався одностатевими парами, оскільки національне законодавство не допускало укладення одностатевих шлюбів. Водночас із набуттям 2 жовтня 2017 року чинності Закону про право на укладення шлюбу особами однієї статі (Gesetz zur Einführung des Rechts auf Eheschließung für Personen gleichen Geschlechts) Закон про довічне партнерство втратив чинність.

У цивільному законодавстві Франції питанням регулювання відносин зареєстрованого партнерства присвячено статті 515.1-515.7-1 Розділу ХІІІ (Titre XIII: Du pacte civil de solidarité et du concubinage) ${ }^{12}$ Пакту цивільної солідарності (Du pacte civil de solidarité).

Пакт цивільної солідарності визначається як договір, що укладається між двома фізичними особами різної або однієї статі для організації їх спільного життя (ст. 515-1 ЦК Франції). Перешкодами для укладення Пакту цивільної солідарності є наявність між особами прямої лінії споріднення або бокової лінії споріднення до третього ступеня включно; перебування хоча б однієї зі сторін у зареєстрованому шлюбі або іншому зареєстрованому партнерстві (ст. 515-2 ЦК Франціi).

11 The Registered Partnership Act of Denmark (D/341- H- ML Act No. 372 of June 1, 1989). URL: http://www.inakost.sk/clanky_foto/file/Dansko.pdf (дата звернення: 15.12.2019).

12 Code civil des Français (Version consolidée au 27 juillet 2017). URL: https://www.legifrance. gouv.fr/affichCode.do?idArticle=LEGIARTI000027431993\&idSectionTA=LEGISCTA00000613 6117\&cidTexte=LEGITEXT000006070721\&dateTexte=20170727 (дата звернення: 15.12.2019). 
Пакт цивільної солідарності укладається через декларацію реєстратору муніципалітету. Також можливо укласти Пакт цивільної солідарності в офісі нотаріуса, але він все одне підлягатиме реєстрації муніципалітетом. Пакт цивільної солідарності набуває чинності саме 3 моменту його реєстрації муніципалітетом, що свідчить про його публічний характер. За кордоном Пакт цивільної солідарності може бути укладений у дипломатичному представництві Франції (ст. 515-3 ЦК Франціі).

Умови Пакту цивільної солідарності можуть бути змінені за згодою партнерів. Такі зміни також підлягають реєстрації (ст. 515-3 ЦК Франції).

Пакт цивільної солідарності регулює саме майнові відносини партнерів.

Так, ЦК Франції встановлює, що партнери, що уклали Пакт цивільної солідарності, зобов'язуються проживати разом та надавати один одному матеріальну допомогу та взаємну підтримку. Матеріальна допомога, що надається відповідно до Пакту цивільного партнерства, є пропорційною можливостям кожного з партнерів, якщо інше не передбачено договором між ними (ст. 515-4 ЦК Франції). Стаття 515-4 ЦК Франції також встановлює солідарну відповідальність партнерів перед третіми особами за боргами одного з них за умови, що вони виникли внаслідок задоволення повсякденних потреб партнерів. Винятком з цього правила $є$ ситуації, коли витрати були явно надмірними або якщо їх було понесено без згоди іншого партнера у разі купівлі у розстрочку або позичками, коли вони є такими, що вочевидь перевищують повсякденні потреби.

Щодо особистого майна кожного з партнерів, то кожен з них зберігає повний контроль над таким майном. Водночас у разі, якщо він не може надати доказів, що право на майно виникло у нього до укладення Пакту цивільної солідарності, то таке майно буде вважатися таким, що належить обом партнерам спільно. Так само кожен з партнерів несе особисту відповідальність за боргами, які виникли до укладення Пакту зареєстрованого партнерства (ст. 515-5 ЦК Франції).

Загальновстановлений режим спільної власності майна, що набувається за час зареєстрованого партнерства, а також правовий режим майна, набутого до укладення пакту цивільної солідарності, може бути змінений договором сторін (ст. 515-5-1 ЦК Франції).

Стаття 515-7 ЦК Франції встановлює правила щодо припинення дії Пакту цивільної солідарності. Так, Пакт припиняє дію у разі смерті 486 
одного 3 партнерів або укладення одним з них шлюбу. В обох випадках Пакт припиняє дію з дати, коли відповідний юридичний факт мав місце, а не $з$ дати державної реєстрації.

Пакт цивільної солідарності також може бути розірваний шляхом спільної декларації партнерів або на підставі рішення одного з них. В обох випадках така дія потребує державної реєстрації і дія Пакту вважається припиненою з дати державної реєстрації.

Слід звернути увагу, що, незважаючи на те, що як інститут зареєстрованого партнерства запровадження Пакту цивільної солідарності було спрямовано насамперед на регулювання відносин одностатевих партнерів, близько 95\% таких союзів були укладені саме гетеросексуальними партнерами ${ }^{13}$.

Національному законодавству Угорщини також відомі два види формалізованих сімейних відносин шлюбного характеру - шлюб та зареєстроване партнерство. До національного законодавства Угорщини поняття зареєстрованого партнерства було запроваджено законом 2009 року (далі - Закон Угорщини про зареєстроване партнерство) $)^{14}$, який набрав чинності в липні 2009 року. Якщо шлюб за законодавством Угорщини -це виключно союз чоловіка та жінки, то зареєстроване партнерство, навпаки, укладається між одностатевими партнерами.

Юридичні наслідки зареєстрованого партнерства в основному ідентичні шлюбним відносинам щодо статусу та майнових наслідків. У юридичній літературі вказується на те, що основний принцип у регулюванні зареєстрованого партнерства законодавством Угорщини полягає у тому, що, вирішуючи питання, які не врегульовані Законом Угорщини про зареєстроване партнерство, мають застосовуватись норми законодавства стосовно шлюбу ${ }^{15}$.

Порушення матеріальних або процесуальних умов укладення зареєстрованого партнерства має такі саме наслідки, як і порушення таких вимог під час укладення шлюбу, відповідно, йдеться про неіснуюче зареєстроване партнерство, недійсне зареєстроване партнерство чи про ситуацію, коли офіційна помилка не впливає ані на його існування, ані на дійсність (відсутність двох свідків).

\footnotetext{
13 Дробінова І. Правове регулювання фактичних шлюбних відносин у Франції: досвід для України. Юридичний вісник. 2013. № 3. С. 137.

14 Törvény a bejegyzett élettársi kapcsolatról, az ezzel összefüggő, valamint az élettársi viszony igazolásának megkönnyítéséhez szükséges egyes törvények módosításáról 2009. évi XXIX. URL: https://net.jogtar.hu/jr/gen /hjegy_doc.cgi?docid=a0900029.tv (дата звернення: 15.12.2019).

15 Szeibert O. National Report: Hungary. URL: http://ceflonline.net/wp-content/uploads/ Hungary-IR.pdf (дата звернення: 15.12.2019).
} 
До основних відмінностей у процедурі та матеріальних умовах зареєстрованого партнерства від шлюбу належить, зокрема, те, що зареєстроване партнерство може бути встановлено лише перед реєстратором районного управління міської ради та представницького органу. Допустимий вік для створення зареєстрованого партнерства вісімнадцять років. До того ж, на відміну від шлюбу, за жодних умов не допускається створення зареєстрованого партнерства неповнолітньою особою.

Не допускається створення зареєстрованого партнерства між близькими родичами. Особи, що створюють зареєстроване партнерство, мусять мати повну або часткову цивільну дієздатність. Недієздатність будь-якої сторони призводить до недійсності зареєстрованого партнерства. Недійсність зареєстрованого партнерства 3 цих причин регулюється такими ж положеннями, як і в шлюбі.

Так само, як і реєстрація шлюбу, реєстрація партнерства є публічним актом, що змінює сімейний стан осіб, саме тому у зв'язку з прийняттям Закону Угорщини про зареєстроване партнерство національне законодавство також зазнало змін. Так, зокрема, були внесені відповідні зміни до процедури запису актів громадянського стану.

Подібно до шлюбу зареєстроване партнерство може бути створене перед завідуючим органу, що реєструє акти цивільного стану. Майбутні партнери, як і майбутні подружжя, мають особисто заявляти про свої наміри. Ця заява має ту ж саму мету, що і процедура перед шлюбом, однак через відмінності в суті двох зв'язків, відмінності у концептуальних елементах та можливих юридичних наслідках наявні відмінності між процедурами.

Реєстратор має поінформувати сторони про правові перешкоди та необхідні передумови для створення зареєстрованого партнерства. Своєю чергою потенційні зареєстровані партнери мають зробити заяву перед завідуючим рацсу про відсутність правових перешкод для створення ними зареєстрованого партнерства.

Зареєстровані партнерства мають вужчий діапазон юридичних наслідків, ніж шлюб. Так, на відміну від шлюбу, зареєстроване партнерство не $є$ підставою виникнення права партнерів на спільне прізвище. Крім того, до зареєстрованого партнерства не можуть застосовуватися положення про відносини між батьками та дітьми. Зареєстроване партнерство, на відміну від шлюбу, не є підставою для виникнення презумпції батьківства. Так само до зареєстрованого партнерства не застосовуються положення законодавства щодо 
допоміжних репродуктивних технологій. Неможливе також усиновлення зареєстрованими партнерами дитини.

Водночас норми, що регулюють майнові відносини, є цілком ідентичними тим, що регулюють майнові наслідки шлюбу, тобто правила загального домогосподарства, сімейного стану, подружнього майна і правила використання житла, так само, як це стосується подружжя.

Зареєстроване партнерство припиняється у разі смерті однієї зі сторін або оголошення іiї померлою. Серед правових наслідків припинення зареєстрованого партнерства можна зазначити зміну сімейного статусу партнерів та майнові наслідки.

Так, у разі смерті одного із зареєстрованих партнерів сімейний статус іншого змінюється із «зареєстрованого партнера» на сімейний статус «овдовілий зареєстрований партнер».

3 точки зору права про правонаступництво овдовілий зареєстрований партнер перебуває в одному і тому ж правовому становищі, як законний спадкоємець.

Зареєстроване партнерство може бути розірване на вимогу однієї або за згодою обох сторін. Розірвання зареєстрованого партнерства можливе у двох варіантах. Перший варіант передбачає використання правил Цивільного кодексу, коли розірвання зареєстрованого партнерства відбувається на підставі договору між партнерами.

Розірвання зареєстрованого партнерства можливе також нотаріусом.

Припинення зареєстрованого партнерства нотаріусом може відбутися, якщо:

а) обидва $з$ партнерів згодні на розірвання партнерства і роблять про це спільну заяву;

б) жоден із зареєстрованих партнерів не має дитини, щодо якої зареєстровані партнери несуть спільну відповідальність;

в) зареєстровані партнери погоджуються на використання спільного житла та, за винятком припинення спільної власності на нерухомість, у нотаріальному акті або приватному документі, контрасигнованому адвокатом, погоджуються у питанні про поділ спільного майна.

Припинення зареєстрованого партнерства в нотаріальному порядку неможливе, якщо будь-яка зі сторін визнана недієздатною, є обмежено дієздатною або порушено питання про визнання зареєстрованого партнерства недійсним або неукладеним.

Наслідком припинення зареєстрованого партнерства $є$ зміна статусу: статус «зареєстрованого партнера» змінюється на статус «розведеного зареєстрованого партнера». 
«Зареєстроване партнерство» слід розглядати як об’єднуюче поняття для різних видів такого партнерства, які відрізняються не лише назвою, а іноді мають і істотні відмінності. До перших з них може бути віднесена можливість укладання зареєстрованого партнерства лише одностатевими або як одностатевими, так і різностатевими парами.

Так, крім розглянутих нами вище, ще одним видом зареєстрованого партнерства є місцеве партнерство (local partnership). Цей вид партнерства передбачений законодавством Італії і визначається як союз між двома особами однієї або різної статі без виникнення взаємних прав та обов'язків, що реєструється місцевою владою. Такий вид партнерства може бути названий символічним, оскільки він лише символізує відносини між сторонами. Особливістю ж італійського права є те, що воно не визнає можливості реєстрації сімейних відносин, подібних до шлюбних, між особами однієї статі з причин правового, соціального та релігійного характеру ${ }^{16}$.

Різновидом зареєстрованого партнерства є також регіональне партнерство (regional partnership). Вказаний вид партнерства являє собою вид союзу, яким встановлено, що повнолітні особи однієї статі, не укладаючи шлюбу, можуть укласти договір про спільне життя, зареєструвати його i, як наслідок, створити сімейний союз у вигляді партнерства. Положення про регіональне партнерство міститься в законодавстві Іспанії ${ }^{17}$.

3 огляду на вищенаведене, заресстроване партнерство може бути визначене як союз двох рівноправних та незалежних осіб різної або однієї статі, спрямований на створення сім'ї та укладений у встановленому законом порядку.

Як зазначалося раніше, законодавче врегулювання відносин, що виникають внаслідок зареєстрованого партнерства, дало змогу також вирішити низку правових проблем, що виникають під час створення сімейного союзу особами однієї статі, оскільки у більшості країн наявна імперативна вказівка закону на те, що шлюбом є виключно союз чоловіка та жінки і через національні та релігійні особливостей він не може бути укладений між особами однієї статі.

16 Григор'єва А. Фактичні шлюбні відносини: особливості правового регулювання в Україні та інших державах. Начіональний юридичний журнал: теорія і практика. 2014. № 5. C. $83-89$.

17 Григор'єва А. Фактичні шлюбні відносини: особливості правового регулювання в Україні та інших державах. Національний юридичний журнал: теорія і практика. 2014. № 5. C. $83-89$. 
Повертаючись до законодавства України, слід зазначити, що, враховуючи можливість створення сім'ї на підставі ч. 4 ст. 3 СК України, автоматично виникає можливість застосування до таких осіб положень СК України про можливість договірного регулювання сімейних відносин, передбачену ст. 7 СК України, яка встановлює, що сімейні відносини можуть бути врегульовані за домовленістю (угодою) між їх учасниками.

Нині в Україні робляться перші кроки із запровадження інституту зареєстрованого партнерства. 25 серпня 2015 року Президентом України було підписано Указ «Про затвердження Національної стратегії у сфері права людини». Зазначена Стратегія спрямована на «об'єднання суспільства довкола розуміння цінності прав і свобод людини, які захищаються на основі принципу рівності та без дискримінації» ${ }^{18}$. Одними зі стратегічних напрямів визначено попередження та протидію дискримінації. 3 метою забезпечення практичної реалізації положень зазначеної Стратегії 23 листопада 2015 року Кабінетом Міністрів України було затверджено «План дій з реалізації Національної стратегії у сфері прав людини на період до 2020 року», яким передбачено, серед іншого, до II кварталу 2017 року розробити та подати на розгляд Кабінету Міністрів України проєкт закону про легалізацію зареєстрованого цивільного партнерства для різностатевих і одностатевих пар з урахуванням майнових та немайнових прав та наслідування майна, утримання одного партнера іншим у разі непрацездатності, конституційного права не свідчити проти свого партнера ${ }^{19}$. Але станом на лютий 2020 року цілей, заданих вищеназваним планом, не було реалізовано. Що стосується термінології, то законодавець мав намір назвати такий вид співжиття саме зареєстрованим цивільним партнерством. Ми ж, своєю чергою, грунтуючись на європейській практиці, вважаємо за доцільне використовувати і на законодавчому рівні закріпити термін «зареєстроване партнерство».

Прийняття зазначеного Плану дій викликало широкий резонанс у засобах масової інформації (ЗМІ) в основному під гаслом, що в Україні планується легалізувати одностатеві шлюби. 3 точки

\footnotetext{
18 Указ Президента України від 25.08.2015 № 501/2015 «Про затвердження Національної стратегії у сфері прав людини». URL: http://www.president.gov.ua/documents/5012015-19364 (дата звернення: 15.12.2019).

19 Розпорядження Кабінету Міністрів України від 23.11.2015 № 1393-р. «Про затвердження плану дій з реалізації Національної стратегії у сфері прав людини на період до 2020 року». URL: http://www.kmu.gov.ua/control/uk/cardnpd?docid=248740679 (дата звернення: 17.12.2019).
} 
зору стратегії ЗМІ це зрозуміло, оскільки якщо написати просто про зареєстроване партнерство, то це викликає набагато меншу реакцію, ніж «одностатевий шлюб», обговорення питань, пов'язаних 3 яким, останніми роками набуває все більшої активності, адже питання сім'ї та шлюбу, на відміну від багатьох інших правових аспектів, стосуються життя практично кожної людини. 3 іншого боку, на жаль, в юридичній науковій літературі такої активності не спостерігається. Справді, тема не лише складна, а й певною мірою провокаційна, оскільки зачіпає не лише правові, а й морально-етичні питання, що зумовлює іiі сприйняття іноді з діаметрально протилежних позицій.

\section{2. Фактичні шлюбні відносини як підстава створення сім'ї за законодавством України та країн-членів СС}

Досліджуючи питання шлюбу та фактичних шлюбних відносин у Франції та Німеччині, К. Кёппен (Katja Köppen) звертає увагу на те, що протягом тривалого часу це було досить поширене явище, оскільки існувала значна кількість законодавчих перешкод для укладення шлюбу. Так, зокрема, у Німеччині лише у 1871 році було скасовано перешкоди для укладення шлюбу всіма групами населення, але лише у період 1950-60-х років, коли було скасовано, зокрема, економічні перешкоди для укладення шлюбу, саме шлюб починає переважати у підставах створення сім’ї. Зрозуміло, що така ситуація призводила до появи значної кількості незаконнонароджених дітей, хоча їх більшість визнавалася батьком. Але це не означає, що така ситуація заохочувалась державою. Скоріше, навпаки.

Існувало, але не заохочувалося співжиття і у Франції, де взагалі починаючи з XIX століття саме шлюб вважався привілейованою та єдиною юридично визнаною формою союзу між чоловіком та жінкою. Певний період ситуація була більш лібералізованою, а саме з 1789 до 1793 року, за часів Великої французької буржуазної революції, коли питання сім'ї та шлюбу розглядалися як виключно приватноправові. Проте з прийняттям у 1804 році Цивільного кодексу Франції (Кодексу Наполеону) запроваджується єдина визнана модель сім’ї- подружжя та його діти ${ }^{20}$.

У юридичній літературі слушно вказується на те, що ставлення до співжиття у країнах романо-германської правової системи тривалий час не просто ігнорувалося, а було об'єктом досить негативного

20 Köppen K. Marriage and cohabitation in Western Germany and France. Dissertation. Rostock, Universität Rostock. 2011.Pp. 53-54.

492 
ставлення. Крім того, діти, народжені в такому співжитті, вважалися незаконнонародженими, теоретично особи, що перебували у фактичних шлюбних відносинах, могли піддаватися кримінальному переслідуванню. Такий порядок проіснував, зокрема, в Італії до 1968, у Німеччині - до 1970, у Норвегії - до 1973 року ${ }^{21}$.

Якщо говорити про національний досвід, то ставлення до юридичного визнання фактичних шлюбних відносин постійно змінювалося. Так, говорячи про найбільш наближену до сучасності принципову зміну у правовому регулюванні цього питання, це була зміна від фактичного їх прирівнювання до зареєстрованого шлюбу (1926-1944 роки) до практично повного невизнання. Причому останній підхід по-різному оцінюється в юридичній літературі. Так, на думку Г.К. Матвєєва, причиною відмови радянської держави у 1944 році від надання певного правового статусу фактичним шлюбним відносинам було те, що лише зареєстрований шлюб здатен створити найбільші гарантії захисту прав економічно залежної жінки, оскільки звільняв їі від процедури доказування існування фактичних шлюбних відносин у суді ${ }^{22}$. Іншу позицію висловлює М.М. Виборнова, яка вважає, що скасування визнання фактичних шлюбів найменшою мірою відповідало інтересам жінок, оскільки ані держава, ані хто-небудь ще не міг заборонити вступати у фактичні шлюбні відносини, проте захист їм уже не надавався. Якщо раніше особи, що перебували у фактичних шлюбних відносинах, незважаючи на певні труднощі в доказуванні, все ж таки могли розраховувати на підтримку з боку закону, то їх було позбавлено цієї можливості. До того ж украй ускладнена процедура розірвання шлюбу призводила до зменшення кількості бажаючих укладати офіційний шлюб ${ }^{23}$. Дослідниця наводить цілу низку аргументів на користь необхідності законодавчого врегулювання фактичних шлюбних відносин, таких як: наявність правових традицій; значне поширення фактичних шлюбних відносин серед населення; необхідність захисту інтересів громадян, які, вступаючи в такі відносини, не замислюються над наслідками,

\footnotetext{
21 Выборнова М.М. Фактический брак мужчины и женщины в гражданском и семейном законодательстве и доктрине : дис. на соиск. уч. степ. канд. юрид. наук : спец. 12.00.03. Москва, 2011. С. 16.

22 Матвеев Г.К. Советское семейное право : учебник. Москва : Юрид. лит., 1985. С. 57.

23 Выборнова М.М. Фактический брак мужчины и женщины в гражданском и семейном законодательстве и доктрине : дис. на соиск. уч. степ. канд. юрид. наук : спец. 12.00.03. Москва, 2011. С. 33.
} 
та захист інтересів дітей; необхідність інтернаціоналізації правового регулювання в умовах, коли фактичні шлюбні відносини визнаються законодавством значної кількості країн ${ }^{24}$.

Нині спостерігається тенденція кількості пар, що обирають фактичне співжиття. У сучасних дослідженнях це пояснюється з різних позицій: від зростання індивідуалізму та руйнування інституту традиційної сім’ї до простого бажання людей будувати сім’ю на менш формалізованих засадах ${ }^{25}$.

Аналіз літератури дає можливість виокремити три основні причини створення особами сім’і на підставі фактичних шлюбних відносин.

По-перше, це небажання вступати у формалізовані відносини (шлюб). Тут ми можемо говорити про фактичні шлюбні відносини як альтернативу шлюбу.

По-друге, це коли фактичні шлюбні відносини виступають проміжним етапом до укладання шлюбу. Це так звані «пробні шлюби».

Як перший, так і другий варіант - це наслідок вільного вибору осіб. Ідеться про них лише у разі, коли немає жодних законодавчих перешкод для укладання особами шлюбу.

Третій варіант виникає у разі принципової неможливості осіб укласти шлюб, зокрема в країнах, де не допускається укладання шлюбу між особами однієї статі. У такому разі йдеться скоріше про квазішлюбні відносини.

Незалежно від того, йдеться про різностатевих або одностатевих партнерів, шлюб у законодавстві України та законодавстві країн-членів ЄC вимагає надання йому певної форми, що розглядається як конститутивна ознака шлюбу. Іншим варіантом надання відносинам форми, визнаної законом, є зареєстроване партнерство. Саме відсутність конститутивної ознаки за наявності інших дає змогу виділити такий вид шлюбних відносин, як проживання однією сім'єю жінки та чоловіка без реєстрації шлюбу. Причому кількість таких сімей є досить високою і її обирають, за даними статистичних досліджень, приблизно 10\% усіх осіб репродуктивного віку ${ }^{26}$.

\footnotetext{
24 Выборнова М.М. Фактический брак мужчины и женщины в гражданском и семейном законодательстве и доктрине : дис. на соиск. уч. степ. канд. юрид. наук : спец. 12.00.03. Москва, 2011. C. 40-41.

25 Barlow A. Cohabitation, Marriage and the Law: Social Change and Legal Reform in the 21st Century. Hart Publishing, Oxford and Portland, Oregon, 2005. P. ${ }^{14}$.

26 Кац М.Н. Формы современной украинской семьи: аксиологический аспект. Вісник СевНТУ : збірник наукових праць. 2012. Випуск 126. С. 55.
} 
Слід одразу зазначити, що не лише на побутовому рівні, а навіть в юридичній літературі є певна плутанина стосовно термінології з цього питання. Так, сталим терміном для позначення такого виду відносин став термін «цивільний» або «громадянський» шлюб. Водночас слід зазначити, що він не відповідає сутності цих відносин, оскільки «цивільний» або «громадянський» шлюб історично використовується для позначення шлюбу, який було зареєстровано світською владою (залежно від національних правил з цього питання це може бути міський муніципалітет, мерія, державний орган рацс тощо). Тобто у більш загальному формулюванні йдеться про шлюб, правозгідність якого була підтверджена державою, на відміну від шлюбу, укладеного за церковним обрядом.

Історія виникнення терміна «цивільний» або «громадянський» шлюб пов'язана з публікацією 20 лютого 1919 року Декрету Раднаркому УСРР «Про громадянський шлюб і про ведення книг запису актів громадянського стану» від 17 лютого 1919 року. Декрет запроваджував громадянський шлюб як єдину форму шлюбу замість церковного шлюбу, який з цього моменту не мав правових наслідків. Водночас нововведення не одразу отримало сприйняття 3 боку суспільства. Ще досить тривалий час «громадянський» шлюб сприймався як щось незрозуміле, несправжнє. Поступово, коли світська форма шлюбу стає усталеною, термін «громадянський» шлюб починають за звичкою використовувати для позначення сімейних відносин чоловіка і жінки, шлюб між якими не зареєстровано.

Ще один історичний термін, який досить часто застосовується для позначення фактичних шлюбних відносин, - це «конкубінат». Сам термін було запозичено з римського приватного права, у якому він позначав сімейні відносини чоловіка та жінки, які не могли укласти законний римський шлюб.

Оскільки нині законодавство пропонує доволі незручний для викладення термін «жінка та чоловік, які проживають однією сім'єю, але не перебувають у шлюбі між собою», далі по тексту будуть використовуватись терміни «фактичне подружжя», «фактичний шлюб», «фактичні шлюбні відносини», що повністю відповідає суті зазначених відносин.

Слід зазначити, що у юридичній літературі немає єдиного підходу до розуміння фактичних шлюбних відносин. Іноді можна побачити підхід, за яким до «фактичних шлюбів» відносять, крім співжиття (cohabitation), такі види союзів, як прийняті в окремих країнах різні 
види партнерства, зокрема зареєстроване партнерство ${ }^{27}$. На нашу думку, з такою позицією погодитись не можна, оскільки зареєстроване партнерство є окремим правовим інститутом.

Аналіз національного законодавства України дає змогу впевнено стверджувати, що фактичні шлюбні відносини є підставою для створення сім’ї. У цьому разі будуть передбачені ч. 4 ст. 3 СК України «інші» підстави створення сім'ї, що «не заборонені законом і такі, що не суперечать моральним засадам суспільства». Крім того, такі відносини відповідають положенню ч. 2 ст. 3 СК України, відповідно до якого сім'ю складають особи, які спільно проживають, пов'язані спільним побутом, мають взаємні права та обов'язки. Таким чином, хоча чоловік та жінка, які проживають однією сім'єю, але не перебувають у шлюбі між собою, не набувають статусу подружжя, вони перебувають у сімейних відносинах. Таку саме позицію висловлює i 3.В. Ромовська, вказуючи, що фактичні шлюбні відносини зумовлюють не статус подружжя, а статус сім'ї28. М.В. Антокольська виходячи $з$ того, що фактичні шлюбні відносини набувають дедалі більшого поширення, наголошувала на хибності підходу, коли такі відносини не породжують жодних правових наслідків. «Фактичний шлюб, - наголошує вона, - не слід прирівнювати до зареєстрованого повністю, але за ним доцільно було б визнати деякі правові наслідки у сфері майнових відносин», зокрема за чоловіком, що проживає тривалий час у фактичних шлюбних відносинах, можна було б визнати право на аліменти, на спадкоємство згідно із законом, а також можна прямо дозволити фактичному подружжю укладати шлюбні угоди, у тому числі й з умовою про поширення на їхнє майно режиму спільної сумісної власності подружжя ${ }^{29}$. Подібну позицію висловлює i М.М. Виборнова, яка вказує на те, що позиція ігнорування правом цього поширеного явища буде хибною. Дослідниця слушно вказує на те, що право має враховувати актуальні соціальні тенденції і відповідати ним: суспільство найчастіше сприймає таких співмешканців як пару, сім'ю, тоді як держава та право розглядають їх як

27 Войнаровская О. Правовое регулирование фактических брачных отношений по законодательству зарубежных стран (на примере отдельных европейских стран). Legea și viața: Publicaţie ştiinţifico-practică. 2015. № 4/3. c. 12. URL: http://www.legeasiviata.in.ua/ archive/2015/4-3/4.pdf (дата звернення: 15.12.2019).

28 Ромовська 3.В. Україна творить європейське сімейне право. Право України. 2013. № 10. C. 14.

29 Антокольская М.В. Лекции по семейному праву. Москва : Юрист, 1995. С. 75. 
незалежних, сторонніх одне одному осіб ${ }^{30}$. На думку автора, фактичні шлюбні відносини мають визнаватися сімейно-правовим інститутом, оскільки для них характерні ознаки сімейних відносин (особисто-довірчий характер, тривалість існування, виникнення лише між фізичними особами, спільне проживання, ведення спільного господарства тощо $)^{31}$. В.А. Ватрас також вказує на «наявність у жінки та чоловіка, що проживають однією сім'єю, але не перебувають у шлюбі між собою та будь-якому іншому шлюбі (фактичні шлюбні відносини), сімейної правосуб' єктності» ${ }^{32}$.

Проте слід зазначити, що чимало юристів-науковців уперто не хотіли визнати сім'єю жінку та чоловіка, які спільно проживали не один рік, а навіть тридцять. Дещо поміркованою була позиція тих, хто допускав створення ними сім’і, але лише у разі народження дитини ${ }^{33}$. Європейський суд з прав людини, розглядаючи справу Кичана, зауважив, що відносини де-факто, як і відносини, що грунтуються на шлюбі, можуть вважатися сімейним життям. У справі «Джонсон проти Ірландії» було встановлено, що заявники прожили спільно понад 15 років. На цій підставі Європейський суд зробив висновок про те, що вони є сім'єю, а тому мають прав на захист, незважаючи на те, що їхній зв'язок існує поза шлюбом ${ }^{34}$.

Слід зазначити, що, хоча фактичні шлюбні відносини $є$ підставою створення сім'ї і у сфері майнових відносин фактичне подружжя має низку спільних положень в їх правовому регулюванні з правовим регулюванням таких відносин між чоловіком та жінкою, які перебувають у шлюбі, висновок про те, що ці дві категорії осіб зрівняно в їх правовому статусі $\epsilon$ неправильним.

Так, на відміну від подружжя, яке вважається сім'єю, і тоді, коли дружина та чоловік у зв'язку з навчанням, роботою, лікуванням, необхідністю догляду за батьками, дітьми та з інших поважних причин не проживають спільно, обов'язковою ознакою фактичних шлюбних відносин є спільне проживання.

30 Выборнова М.М. Фактический брак мужчины и женщины в гражданском и семейном законодательстве и доктрине : дис. на соиск. уч. степ. канд. юрид. наук : спец. 12.00.03. Москва, 2011. С. 3.

31 Там само, с. 6.

32 Ватрас В.А. Суб’єкти сімейних правовідносин : автореф. дис. на здобуття ступеня канд. юрид. наук : 12.00.03. Київ, 2008. С. 8.

33 Ревуцька І.Е., Булеца С.Б. «Інші» підстави створення сім’ї. Науковий вісник Херсонського держ. ун-ту. 2016. Випуск 6. Т. 1. С. 119.

34 Чешир Д. Международное частное право. Москва : Прогресс, 1982. 496 с., с. 11. 
На фактичне подружжя не поширюються права та обов'язки, що виникають у разі реєстрації шлюбу, а також особисті немайнові права та обов'язки дружини та чоловіка. Так, зокрема, на фактичне подружжя не поширюється норма стосовно права на вибір прізвища у разі реєстрації шлюбу (ст. 35 СК України), відповідно до якої наречені мають право обрати прізвище одного з них як спільне прізвище подружжя або надалі іменуватися дошлюбними прізвищами. Наречена, наречений також мають право приєднати до свого прізвища прізвище нареченого, нареченої. Якщо вони обоє бажають мати подвійне прізвище, за їхньою згодою визначається, з якого саме прізвища воно буде починатися. Так само на них не поширюється норма ст. 53 СК України щодо зміни прізвища. У зв'язку з цим запропоноване в юридичній літературі визначення, що «фактичні шлюбні відносини» - це «особисті немайнові відносини, а також відносини щодо спільно набутого майна та взаємного утримання між жінкою та чоловіком, які проживають однією сім'єю, не перебувають у шлюбі між собою та в будь-якому іншому шлюбі» ${ }^{35}$ навряд чи можна вважати повністю коректним 3 правової точки зору, адже особисті немайнові відносини фактичного подружжя не $\epsilon$ нині предметом правового регулювання, хоча частина з них, безперечно, виникає між особами, що перебувають у таких відносинах.

Деякі з урегульованих законодавством аспектів щодо особистих немайнових відносин подружжя можуть бути 3 суто «зовнішньої» позиції «реалізовані» завдяки іншим правовим інститутам. Так, наприклад, проблему, пов'язану з неможливістю мати спільне прізвище, може бути вирішено за допомогою норми ст. 295 ЦК України, яка встановлює право фізичної особи, яка досягла шістнадцяти років, на власний розсуд змінити своє прізвище та (або) власне ім'я. Але слід мати на увазі, що в цьому разі прізвище буде не спільним, а просто однаковим.

Ще однією принциповою відмінністю $є$ те, що у фактичних шлюбних відносинах не виникає презумпція батьківства, встановлена ч. 1 ст. 122 СК України, відповідно до якої дитина, яка зачата i (або) народжена у шлюбі, вважається такою, яка походить від подружжя. Питання визначення походження дитини, таким чином, у фактичних шлюбних відносинах має вирішуватись відповідно до ст. 125 СК України.

Майнові права фактичного подружжя регулюються національним законодавством досить докладно. Так, ст. 74 СК України встановлює

\footnotetext{
35 Липець Л.В. Врегулювання шлюбних та подібних відносин законом та договором : автореф. дис. на здобуття ступеня канд. юрид. наук : 12.00.03. Київ, 2009. С. 7. 
режим спільної сумісної власності майна, набутого жінкою та чоловіком, які проживають однією сім'єю, але не перебувають у шлюбі між собою або в будь-якому іншому шлюбі, якщо інше не встановлено письмовим договором між ними. Частина 2 зазначеної статті також поширює положення глави 8 СК України «Право спільної сумісної власності подружжя» на майно, що є об'єктом права спільної сумісної власності жінки та чоловіка, які не перебувають у шлюбі між собою або в будь-якому іншому шлюбі.

Таким чином, ст. 74 СК України передбачає поширення режиму спільної сумісної власності на майно осіб, що перебувають у фактичних шлюбних відносинах, набуте ними за час спільного проживання. Слід зазначити, що у первісній редакції цісї статті йшлося про право на майно жінки та чоловіка, які проживають однією сім'єю, але не перебувають у шлюбі між собою. Законом України від 22.12.2006 року № 524-V «Про внесення змін до Сімейного та Цивільного кодексів України» до зазначеної статті було внесено зміни, якими конкретизувалося, що режим спільної сумісної власності поширюється на майно осіб, що перебувають у фактичних шлюбних відносинах, набуте ними за час спільного проживання, лише за умови, що жодна з них не перебуває в будь-якому іншому шлюбі. Таким чином було усунено можливість поширення режиму спільної сумісної власності на майно, набуте особою, яка перебуває у шлюбі, але фактично проживає однією сім'єю 3 іншою особою, на майно, набуте під час такого проживання. Можна зробити висновок, якщо одна з осіб, що не перебувають у шлюбі, але фактично проживають однією сім'єю, перебуває у зареєстрованому шлюбі, на майно, набуте під час такого проживання, буде поширюватись режим спільної часткової власності.

Водночас слід звернути увагу ще на такий момент, як положення ч. 4 ст. 368 ЦК України, що встановлює, що майно, набуте в результаті спільної праці та за спільні грошові кошти членів сім’ї, $є$ їхньою спільною сумісною власністю, якщо інше не встановлено договором, укладеним у письмовій формі. Таким чином, принциповим тут може стати питання: наскільки спільне проживання жінки і чоловіка, коли одна зі сторін перебуває в зареєстрованому шлюбі, суперечить моральним засадам суспільства (оскільки законом це не заборонено) і чи можуть вони вважатися сім'єю і, відповідно, набувати статусу членів сім’і, щоб на них могло бути поширено положення ч. 2 ст. 3 СК України. Тим паче, що існує норма ч. 6 ст. 57 СК України, відповідно до якої суд може визнати особистою приватною власністю дружини/чоловіка 
майно, набуте нею/ним за час їхнього окремого проживання у зв'язку 3 фактичним припиненням шлюбних відносин. Таким чином, доведення факту фактичного припинення шлюбних відносин дає можливість «вивести» майно сторін із-під режиму спільної сумісної власності зареєстрованого подружжя. Подальше доведення проживання однією сім'єю з іншою особою, звичайно, не дасть змоги застосувати норму ст. 74 СК України, проте цілком імовірним є застосування норми ст. 368 ЦК України.

У юридичній літературі також висловлюється позиція, що у разі застосування ст. 74 СК України «необхідно довести, що чоловік та жінка проживають однією сім'єю і не перебувають у шлюбі між собою або в будь-якому іншому зареєстрованому шлюбі» ${ }^{36}$. У зв'язку 3 цим вказується на хибність позиції, коли нотаріуси «автоматично застосовують положення ст. 65 СК України до всіх осіб, які не перебувають у зареєстрованому шлюбі. Виникає питання: чи не порушує нотаріус права і свободи громадян, визначені Конституцією України, 3'ясовуючи факт перебування особи у фактичних шлюбних відносинах, під час посвідчення правочинів і оформлення цього факту заявою, зокрема, у частині заборони втручання в особисте та сімейне життя (ст. 32)?» ${ }^{37}$.

В.А. Ватрас також указує на наявність у СК України істотних суперечностей щодо правової регламентації інституту фактичного подружжя, зокрема «у частині відсутності відповідних критеріїв для визнання таких відносин судом» ${ }^{38}$.

Стаття 91 СК України встановлює право жінки, чоловіка, які не перебувають у шлюбі між собою, на утримання. На відміну від ст. 71 СК України, у цьому разі не йдеться про вимогу неперебування однієї зі сторін в іншому зареєстрованому шлюбі. Проте висувається інша вимога - проживання однією сім'єю тривалий час. Слід зазначити, що «тривалий час» $є$ оціночним поняттям, а тому суди часто по-різному підходять до оцінки тривалості проживання. Так, наприклад, у рішенні Першотравенського міського суду Дніпропетровської області у справі № 186/1100/15-ц від 17 вересня 2015 року вказується, що тривалим слід вважати «термін не менше десяти років». Водночас Баглійським

\footnotetext{
36 Дякович М.М., Сеник С.В. Правове регулювання «фактичних шлюбних відносин». Вісник Верховного Суду Украӥни. 2011. № 2. С. 41.

37 Там само, с. 42.

38 Ватрас В.А. Суб'єкти сімейних правовідносин : автореф. дис. на здобуття ступеня канд. юрид. наук : 12.00.03. Київ, 2008. С. 8.
} 
районним судом м. Дніпродзержинська Дніпропетровської області у рішенні у справі № 2-849/10 від 25 лютого 2010 року тривалим було визнано спільне проживання позивачки та відповідача протягом чотирьох років (з 2005 по 2009 рік).

Отже, фактичні шлюбні відносини є однією з підстав створення сім’ї. Такий підхід цілком відповідає Конституції України, яка передбачає право на особисту свободу, що дає підстави стверджувати, що кожна людина має право сама обирати форму створення сім'ї (перебування у зареєстрованому шлюбі або перебування у фактичних шлюбних відносинах). Саме п. 2 ст. 3 СК України закріплює це конституційне право чоловіка і жінки, а ст. 5 СК України гарантує, що «ніхто не може зазнавати втручання у його сімейне життя, крім випадків, установлених Конституцією». Таким чином, незалежно від підстав створення сім'ї, правовий статус її учасників поставлений в однакову правову площину ${ }^{39}$.

Говорячи про правову природу фактичних шлюбних відносин, слід зазначити, що за законодавством України фактичні шлюбні відносини мають бути віднесені до юридичних станів, а сам вступ у фактичні шлюбні відносини є юридичним фактом, оскільки має за наслідок виникнення сімейних правовідносин. Водночас у країнах, де фактичні шлюбні відносини ігноруються законом, вони не будуть розглядатися як юридичний стан. У юридичній літературі також висловлюється позиція стосовно доцільності розглядати фактичний шлюб у разі визнання його державою як сімейно-правовий інститут особливого роду (sui generis) ${ }^{40}$.

Оскільки законодавець закріпив принцип моногамії у шлюбних відносинах, перебування одного із сепарованого подружжя у фактичних шлюбних відносинах з іншою особою суперечить моральним засадам суспільства, тому такі відносини не можуть вважатися сімейними ${ }^{41}$.

Другий аспект, на який слід звернути увагу, - це відсутність жодних перешкод у врегулюванні відносин фактичного подружжя договором, причому така можливість не виключається не залежно від регулювання їх відносин СК України, оскільки ст. 9 «Регулювання сімейних

\footnotetext{
39 Ревуцька І.Е. «Інші» підстави створення сім'ї. Visegrad Journal on Human Rights. 2017. P. 1. № 1. Р. 99.

40 Выборнова М.М. Фактический брак мужчины и женщины в гражданском и семейном законодательстве и доктрине : дис. на соиск. уч. степ. канд. юрид. наук : спец. 12.00.03. Москва, 2011. С. 53.

41 Ревуцька І.Е., Булеца С.Б. «Інші» підстави створення сім’ї. Науковий вісник Херсонського держ. ун-ту. 2016. Випуск 6. Т. 1. С. 119.
} 
відносин за домовленістю (договором) сторін» СК України встановлює можливість договірного регулювання сімейних відносин як для осіб, відносини між якими ним регулюються (ч. 1), так і для осіб, чиї сімейні (родинні) відносини ним не регулюються (ч. 2). Сдина вимога - зміст цього договору не має суперечити вимогам СК України, інших законів України та моральним засадам суспільства. У юридичній літературі пропонується поняття «конкубінатного договору» як договору про спільне проживання фактичних жінки та чоловіка однією сім'єю без реєстрації шлюбу. Такий договір пропонується укладати в письмовій формі з обов'язковим нотаріальним посвідченням і вважати його непоіменованим договором, який є підставою виникнення сім' ${ }^{42}$. На нашу думку, врегулювання фактичних шлюбних відносин саме договором $\epsilon$ найбільш правильною позицією.

Законодавство країн-членів СС ставиться до фактичних шлюбних відносин досить «стримано». Водночас як будь-яке фактично існуюче явище фактичні шлюбні відносини підлягають правовому регулюванню, яке здійснюється або окремими законами, або шляхом включення відповідних положень до цивільного законодавства.

Так, наприклад, окремим Законом про співжиття (Sambolag, 2003) регулюються відносини співмешканців у Швеції. Метою прийняття Закону про співжиття стало прагнення забезпечити мінімальний захист прав більш уразливого з партнерів у разі припинення співжиття ${ }^{43}$. Закон регулює порядок поділу помешкання та спільного майна.

Трапляються варіанти, коли фактичні шлюбні відносини визнаються лише в окремих регіонах країни. Як приклад можна назвати Іспанію, де відносини співжиття не врегульовані на загальнонаціональному рівні, але окремі закони було прийнято, зокрема, у Каталонії, Валенсії, Наваррі тощо.

Положення Закону поширюються на відносини як одностатевих, так і різностатевих партнерів. Під співмешканцями § 1 Закону розуміє двох осіб, жоден з яких не перебуває у шлюбі або зареєстрованому партнерстві, які постійно проживають разом і ведуть спільне господарство. На відміну від відносин шлюбу або зареєстрованого партнерства, цей акт не регулює питання, пов’язані зі спадкуванням або зобов'язаннями. На співмешканців також не поширюються

\footnotetext{
42 Старчук О.В. До питання посвідчення нотаріусом конкубінатного договору. Право і суспільство. 2017. № 1. С. 81.

43 Informal relationships: Sweden. National Legislation: Sweden. Commission on European Family Law. Country reports by subject. URL: http://ceflonline.net/wp-content/uploads/SwedenIR-Legislation.pdf (дата звернення: 15.12.2019).
} 
положення стосовно застосування допоміжних репродуктивних технологій ${ }^{44}$.

ЦК Франції присвячує безпосередньо співжиттю (конкубінату) лише одну статтю. Так, ст. 515-8 ЦК Франції встановлює, що співжиття - це де-факто союз, що характеризується спільним життям з ознаками стабільності та безперервності, осіб різної або однієї статі, що проживають у парі. Водночас окремі положення, що стосуються співмешканців так само як подружжя або зареєстрованих партнерів, містяться також у Кодексі соціальної безпеки (Code de la sécurité sociale). Так, ст. L 434-8 містить норму стосовно права на пожиттєві виплати у разі загибелі співмешканця внаслідок аваpiï. Відповідно до ст. L434-9 це право втрачається у разі укладання шлюбу, зареєстрованого партнерства або вступу у нові відносини співжиття ${ }^{45}$.

Німецьке цивільне законодавство фактичні шлюбні відносини не визнає. Водночас Німецьке цивільне уложення ${ }^{46}$ опосередковано регулює певні аспекти співжиття. Як приклад можна навести ст. $1600 \mathrm{~d}$ стосовно встановлення батьківства (оскільки йдеться про презумпцію батьківства не стосовно саме чоловіка в шлюбі, а про того, хто в певний період мав зв'язок з матір'ю дитини).

Угорське законодавство визнає дві форми альтернативних сімейних відносин: зареєстроване партнерство та співжиття. Зареєстроване партнерство докладно розглядалося у цьому дослідженні. Співжиття регулюється угорським законодавством починаючи з 1959 року, але за ці роки відповідні норми зазнали істотної модифікації, хоча саме розуміння співжиття залишилося незмінним.

Хоча ззовні різниця між зареєстрованим партнерством та співжиттям не є очевидною, але відповідно до національного законодавства це принципово різні інститути. Тоді як зареєстроване партнерство змінює сімейний стан особи, тобто виступає підставою створення сім’і, має багато спільних ознак зі шлюбом у вигляді однакових юридичних наслідків, то співжиття тягне права та обов'язки, подібні до тих, що

\footnotetext{
44 Sambolag utfärdad den 12 juni 2003. URL: http://www.notisum.se/rnp/sls/sfs/20030376.pdf (дата звернення: 15.12.2019).

45 Code de la sécurité sociale des Français (Version consolidée au 6 novembre 2017). URL: https://www.legifrance.gouv.fr/affichCode.do?cidTexte=LEGITEXT000006073189 (дата звернення: 15.12.2019).

46 Bürgerliches Gesetzbuch (BGB) (Bürgerliches Gesetzbuch in der Fassung der Bekanntmachung vom 2. Januar 2002 (BGB1. I S. 42, 2909; 2003 I S. 738), das zuletzt durch Artikel 2 des Gesetzes vom 17. Juli 2017 (BGBl. I S. 2513) geändert worden ist). URL: https://www.gesetze-im-internet.de/bgb/BGB.pdf (дата звернення: 15.12.2019).
} 
випливають зі шлюбу. Співжиття може існувати між партнерами як різної, так і однієї статі.

Висновок стосовно можливості співжиття між особами однієї статі був зроблений Конституційним судом Угорщини ще у 1995 році під час розгляду справи за заявою про визнання цього положення ЦК Угорщини таким, що суперечить Конституції. Проаналізувавши національне законодавство, Конституційний суд Угорщини дійшов висновку, що відносини співмешканців можуть бути прирівняні до відносин утримання, а тому вказівка на неможливість співжиття між особами однієї статі матиме ознаки дискримінації за статевою ознакою ${ }^{47}$.

Правові норми стосовно співжиття містяться в двох книгах ЦК Угорщини. Так, загальні положення про співжиття містяться у Книзі шостій, що регулює зобов'язання, та в Книзі четвертій, що регулює сімейні відносини ${ }^{48}$.

Так, ст. 6:514 встановлює, що співжиття означає, що дві особи проживають разом поза шлюбом в емоційній та фінансовій спільності і ведуть спільне господарство. Обов'язковою умовою, щоб таке проживання було визнано співжиттям у сенсі зазначеної статті, $є$ неперебування жодної 3 цих осіб у шлюбі, партнерстві або співжитті з іншою особою за умови, що вони не $\epsilon$ братами та сестрами. За цих умов співжиття вважається таким до тих пір, поки особи не укладуть шлюб або зареєстроване партнерство або їх відносини не припиняться ${ }^{49}$. Таким чином, аналіз змісту зазначеної статті дає змогу зробити висновок, що співжиття має розглядатися як фактичні відносини, що характеризуються низкою ознак.

За відсутності хоча б однієї з цих ознак відносини не можуть розглядатися як співжиття у сенсі ст. 6:514 ЦК Угорщини ${ }^{50}$. Як виняток тут слід назвати перебування когось зі співмешканців у шлюбі або зареєстрованому партнерстві. Така ситуація не виключає визнання факту співжиття, але лише за умови, що між співмешканцем та його чоловіком/дружиною або зареєстрованим партнером відсутні сімейні відносини. Наявність сімейних відносин i, таким чином, паралельне існування шлюбу (зареєстрованого партнерства) та співжиття виключає визнання останнього таким, що має правові наслідки.

${ }^{47}$ Szeibert O. National Report: Hungary. URL: http://ceflonline.net/wp-content/uploads/ Hungary-IR.pdf (дата звернення: 15.12.2019).

48 Törvény a Polgári Törvénykönyvröl 2013. évi V. URL: https://net.jogtar.hu/jr/gen/hjegy_ doc.cgi?docid=A1300005 TV (дата звернення: 15.12.2019).

49 Törvény a Polgári Törvénykönyvröl 2013. évi V. URL: https://net.jogtar.hu/jr/gen/hjegy_ doc.coi?docid=A1300005 TV (дата звернення: 15.12.2019).

50 Там само. 
Визнаючи відносини співжиттям, судова практика часто додає ще такі додаткові критерії, як: очевидність відносин співмешканців для третіх осіб, стабільний та взаємний характер відносин. Головним критерієм визнання осіб співмешканцями виступає економічний критерій. Проте у разі вирішення конкретних справ суд має та оцінює всі ознаки в їх сукупності ${ }^{51}$.

Співмешканці можуть врегулювати свої відносини за допомогою письмового договору, який підлягає посвідченню адвокатом. До договору можуть бути включені будь-які положення, що регулюють майнові права співмешканців, у тому числі такі, що зазвичай встановлюються для подружжя законом або шлюбним договором. Щодо третіх осіб, то такий договір стосуватиметься їх у разі, якщо він був зареєстрований у відповідному національному реєстрі або якщо співмешканці зможуть довести, що третя особа знала або повинна була знати про існування такого договору та його зміст (ст. 6:514 ЦК Угорщини). У договорі також може бути визначений порядок користування житловим приміщенням, у тому числі і після припинення співжиття (ст. 6:517 ЦК Угорщини) $)^{52}$.

Як загальне правило встановлюється, що, якщо інше не передбачено договором між ними, співмешканці вважаються незалежними у набутті майна під час спільного проживання. Спори стосовно майна вирішуються в судовому порядку. Так само, як і щодо подружжя діє правило стосовно режиму особистої приватної власності майна, набутого до початку спільного проживання.

Стаття 6:515 ЦК Угорщини встановлює, що поділ спільно набутого майна відбувається відповідно до правил про спільну часткову власність. Якщо неможливо визначити внесок кожного з партнерів у набуття майна, він буде вважатися рівним за винятком випадків, коли це явно несправедливо стосовно одного зі співмешканців. Причому ведення домашнього господарства та виховання дітей вважаються діями, що сприяли набуттю майна ${ }^{53}$.

Положення, що регулюють суто сімейні відносини, можуть бути застосовані до співмешканців лише у виключних випадках і стосуються надання утримання після припинення співжиття і користування

51 Szeibert O. National Report: Hungary. URL: http://ceflonline.net/wp-content/uploads/ Hungary-IR.pdf (дата звернення: 15.12.2019).

52 Törvény a Polgári Törvénykönyvröl 2013. évi V. URL: https://net.jogtar.hu/jr/gen/hjegy_ doc.cgi?docid=A1300005 TV (дата звернення: 15.12.2019).

53 Там само. 
спільним житлом після припинення співжиття. Так, для застосування цих норм співмешканці мають проживати разом мінімум протягом одного року та мати спільну дитину ${ }^{54}$.

3 вищезазначеного випливає важливе 3 практичної точки зору питання: як визначити початок та припинення відносин співжиття? Формально вважається, що відносини співжиття починаються, коли наявні всі ознаки, визначені ст. 6:514 ЦК Угорщини: спільне проживання, емоційний та фінансовий зв'язок та ведення спільного господарства. Закінчується воно, коли співмешканці укладають шлюб або зареєстроване партнерство або їх відносини припиняються. Логічно також стверджувати, що співжиття припиняється у разі смерті одного зі співмешканців або оголошення його померлим ${ }^{55}$.

Як бачимо, не всі з цих ознак можуть бути встановлені беззаперечно. Саме тому національна система Угорщини передбачає можливість для співмешканців зафіксувати їхні відносини, подавши відповідну заяву до Реєстру заяв про співжиття, який перебуває у віданні Національної нотаріальної палати Угорщини. Подача такої заяви є добровільною і має деклараційний характер, тобто не тягне правових наслідків, але з суто практичної точки зору наявність зареєстрованої заяви створює презумпцію існування співжиття, а тому така можливість істотно розширює можливості співмешканців у доказуванні існування факту співжиття та захисті своїх прав. Співмешканці або один з них можуть подати заяву про припинення співжиття. Так само така заява не є беззаперечним доказом припинення співжиття, але створює відповідну презумпцію56.

Законодавство більшості країн-членів ЄС іде шляхом урегулювання відносин фактичного подружжя звичайним приватноправовим договором. На нашу думку, саме такий підхід є найбільш обгрунтованим. Мотиви, з яких особи не бажають укладати шлюб, можуть бути різними, але це не означає обов'язок держави «підлаштовуватись» під кожен з них. 3 іншого боку, слід враховувати, що сторони таких відносин обирають їх свідомо, іноді бажаючи таким чином уникнути їх правового регулювання.

Нині в Україні є інститут шлюбу та обговорюється питання про запровадження інституту зареєстрованого партнерства. Щодо

${ }_{54}$ Szeibert O. National Report: Hungary. URL: http://ceflonline.net/wp-content/uploads/ Hungary-IR.pdf (дата звернення: 15.12.2019).

55 Törvény a Polgári Törvénykönyvröl 2013. évi V. URL: https://net.jogtar.hu/jr/gen/hjegy_ doc.cgi?docid=A1300005 TV (дата звернення: 15.12.2019).

${ }_{56}$ Szeibert O. National Report: Hungary. URL: http://ceflonline.net/wp-content/uploads/ Hungary-IR.pdf (дата звернення: 15.12.2019). 
фактичних шлюбних відносин, то вони тому і є фактичними, що не регулюються державою i, відповідно, не мають створювати інших прав та обов'язків, ніж ті, що сторони визначили для себе у приватному порядку, що може бути зафіксовано в такому саме приватноправовому договорі. Небажання сторін або однісї з них укласти такий договір свідчить скоріше про відсутність саме сімейних відносин, оскільки такі відносини передбачають певний рівень довіри та взаємної турботи і є скоріше приводом замислитись про доцільність їх продовження, ніж про доцільність спроб держави створити ілюзію наявності шлюбу для однієї зі сторін.

Водночас, як було показано вище, заслуговує на увагу запозичення угорського досвіду із запровадження можливості державної реєстрації договору фактичного подружжя (конкубінатного договору), що дає можливість, по-перше, встановити презумпцію існування фактичних шлюбних відносин, і по-друге, спростити визначення строків їх існування.

\section{ВИСНОВКИ}

Серед напрямів, що вимагають уваги у разі здійснення гармонізації країн-членів СС у сфері регулювання сімейних відносин, окреме місце посідає створення європейської моделі сімейного союзу на підставах, відмінних від шлюбу. Однією з найбільш поширених таких підстав у країнах-членах $Є С$ є зареєстроване партнерство.

Інститут зареєстрованого партнерства був запроваджений та закріплений на законодавчому рівні в окремих європейських країнах наприкінці минулого століття як відповідь на поширення в суспільстві сімейних відносин між чоловіками та жінками без офіційного укладення шлюбу, а також між особами однісї статі, які тоді в принципі не могли укласти шлюб або легалізувати свої стосунки у будь-який інший спосіб. Він не є суто сімейно-правовим інститутом і має розглядатися насамперед у контексті прав людини. Крім того, інститут зареєстрованого партнерства є особливим правовим інститутом і не має прирівнюватись до шлюбу або фактичних шлюбних відносин.

Звичайною практикою є регулювання відносин зареєстрованого партнерства окремим законодавчим актом. Крім того, окремі положення щодо зареєстрованого партнерства можуть встановлюватись цивільним і сімейним законодавством. Часто, за окремими винятками, що полягають у додаткових вимогах, для укладення зареєстрованого партнерства висуваються такі саме вимоги, як до укладення шлюбу. 
Зареєстроване партнерство може бути визначене як союз двох рівноправних та незалежних осіб різної або однієї статі, спрямований на створення сім’ї та укладений у встановленому законом порядку.

Запровадження інституту зареєстрованого партнерства в Україні дасть змогу вирішити цілу низку питань, що виникають у зв'язку зі спільним проживанням осіб, які з якихось причин не можуть або не бажають укласти шлюб.

Що стосується фактичних шлюбних відносини, то вони є однією з поширених підстав створення сім'ї. У більшості європейських країн фактичні шлюбні відносини не $\epsilon$ предметом правового регулювання і не несуть жодних правових наслідків. Законодавство України регулює відносини фактичного подружжя досить докладно. Практична реалізація деяких законодавчих положень стикається з труднощами, викликаними саме неформальним характером відносин, про які йдеться, неможливістю чіткого визначення часових рамок існування таких відносин, фіксації їх початку та припинення. Водночас із запровадженням у сімейному законодавстві України досить широких можливостей урегулювання відносин членів сім'ї з допомогою договору запроваджений у СК України підхід до регулювання фактичних шлюбних відносин видається сумнівним у своїй доцільності.

\section{АНОТАЦІЯ}

У дослідженні йдеться про такі інститути, як зареєстроване партнерство та фактичні шлюбні відносини. Авторами зроблено спробу дати визначення цим поняттям. Розкрито можливості практичної реалізації зареєстрованого партнерства та фактичних шлюбних відносин як однієї з підстав створення сім’ї. Під час написання цієї статті зроблено порівняльний аналіз їх застосування та закріплення у законодавстві країн-членів СС. I як результат автори дійшли висновку, що перебування у зареєстрованому шлюбі або перебування у фактичних шлюбних відносинах чи зареєстрованому партнерстві є підставами створення сім’і, адже саме такий підхід цілком відповідає Конституції України, яка передбачає право на особисту свободу, що дає підстави стверджувати, що кожна людина має право сама обирати форму створення сім’і, а ст. 5 СК України гарантує, що «ніхто не може зазнавати втручання у його сімейне життя, крім випадків, установлених Конституцією». 


\section{ЛITЕРАТУРА}

1. Barlow A. Cohabitation, Marriage and the Law: Social Change and Legal Reform in the 21st Century. Hart Publishing, Oxford and Portland, Oregon, 2005. $170 \mathrm{p}$.

2. Boele-Woelki K. The principles of European family law: its aims and prospects. Utrecht Law Review. 2005. Volume 1, Issue 2 (December). P. 160-168.

3. Bürgerliches Gesetzbuch (BGB) (Bürgerliches Gesetzbuch in der Fassung der Bekanntmachung vom 2. Januar 2002 (BGBl. I S. 42, 2909; 2003 I S. 738), das zuletzt durch Artikel 2 des Gesetzes vom 17. Juli 2017 (BGBl. I S. 2513) geändert worden ist). URL: https://www.gesetze-im-internet.de/bgb/ BGB.pdf (дата звернення: 15.12.2019).

4. Civil unions and registered partnerships. URL: http://europa.eu/ youreurope/citizens/family/couple/registered-partners/index_en.htm (дата звернення: 15.12.2019).

5. Code civil des Français (Version consolidée au 27 juillet 2017). URL: https://www.legifrance.gouv.fr/affichCode. do ? idArticle=LEGIARTI $000027431993 \&$ id Section TA= LEGISCTA000006136117\&cidTexte=LEGITEXT000006070721\& dateTexte $=20170727$ (дата звернення: 15.12.2019).

6. Code de la sécurité sociale des Français (Version consolidée au 6 novembre 2017). URL: https://www.legifrance.gouv.fr/affichCode.do?cidTe xte=LEGITEXT000006073189 (дата звернення: 15.12.2019).

7. Informal relationships: Sweden. National Legislation: Sweden. Commission on European Family Law. Country reports by subject. URL: http://ceflonline.net/wp-content/uploads/Sweden-IR-Legislation.pdf (дата звернення: 15.12.2019).

8. Köppen K. Marriage and cohabitation in Western Germany and France. Dissertation. Rostock, Universität Rostock. 2011. 299 p.

9. Martin J. English Polygamy Law and the Danish Registered Partnership Act: A Case for the Consistent Treatment of Foreign Polygamous Marriages and Danish Same-Sex Marriages in England. Cornell International Law Journal. 1994. Volume 27. Issue 2. P. 419-446.

10. Sambolag utfärdad den 12 juni 2003. URL: http://www.notisum.se/rnp/ sls/sfs/20030376.pdf (дата звернення: 15.12.2019).

11. Schanda B. A jog lehetõségei a család védelmére. URL: http://ias.jak.ppke.hu/hir/ias/20122sz/09.pdf (дата звернення: 15.12.2019).

12. Szeibert O. National Report: Hungary. URL: http://ceflonline.net/ wp-content/uploads/Hungary-IR.pdf (дата звернення: 15.12.2019).

13. The Registered Partnership Act of Denmark (D/341- H- ML Act No. 372 of June 1, 1989). URL: http://www.inakost.sk/clanky_foto/file/ Dansko.pdf (дата звернення: 15.12.2019). 
14. Törvény a bejegyzett élettársi kapcsolatról, az ezzel összefüggő, valamint az élettársi viszony igazolásának megkönnyítéséhez szükséges egyes törvények módosításáról 2009. évi XXIX. URL: https://net.jogtar.hu/jr/gen /hjegy_doc. cgi?docid=a0900029.tv (дата звернення: 15.12.2019).

15. Törvény a Polgári Törvénykönyvről 2013. évi V. URL: https://net.jogtar. hu/jr/gen/hjegy_doc.cgi?docid=A1300005 TV (дата звернення: 15.12.2019).

16. Validity of marriage or registered partnership. URL: https://www.nyidanmark.dk/en-us/coming_to_dk/work/Accompanyingfamily/Validity_marriage.htm (дата звернення: 15.12.2019).

17. Антокольская М.В. Лекции по семейному праву. Москва : Юрист, 1995. $120 \mathrm{c}$.

18. Ватрас В.А. Суб'єкти сімейних правовідносин : автореф. дис. на здобуття ступеня канд. юрид. наук : 12.00.03. Київ, 2008. 21 с.

19. Войнаровская О. Правовое регулирование фактических брачных отношений по законодательству зарубежных стран (на примере отдельных европейских стран). Legea și viața : Publicaţie ştiințifico-practică. 2015. № 4/3. C. 12-15. URL: http://www.legeasiviata.in.ua/archive/2015/4-3/4.pdf (дата звернення: 15.12.2019).

20. Выборнова М.M. Фактический брак мужчины и женщины в гражданском и семейном законодательстве и доктрине : дис. на соиск. уч. степ. канд. юрид. наук: спец. 12.00.03. Москва, 2011. 218 с.

21. Григор'єва А. Фактичні шлюбні відносини : особливості правового регулювання в Україні та інших державах. Національний юридичний журнал: теория и практика. 2014. № 5. С. 83-89.

22. Дородонова Н.В. Современные тенденции развития форм совместного проживания (на примере Бельгии). Вопросы российского и международного права. 2011. № 2. C. 114-122. URL: http://publishing-vak. ru/file/archive-law-2011-2/9-dorodonova.pdf (дата звернення: 15.12.2019).

23. Дробінова I. Правове регулювання фактичних шлюбних відносин у Франції: досвід для України. Юридичний вісник. 2013. № 3. С. 135-139.

24. Дякович М.М., Сеник С.В. Правове регулювання «фактичних шлюбних відносин». Вісник Верховного Суду України. 2011. № 2. С. 37-43.

25. Кац М.Н. Формы современной украинской семьи: аксиологический аспект. Вісник СевНТУ : збірник наукових праць. 2012. Випуск 126. С. 54-58.

26. Конституція України від 28.06.1996. URL: http://zakon4.rada.gov.ua/ laws/show/254к/96-вр (дата звернення: 15.12.2019).

27. Липець Л.В. Врегулювання шлюбних та подібних відносин законом та договором : автореф. дис. на здобуття ступеня канд. юрид. наук : 12.00.03. Київ, 2009. 20 с.

28. Матвеев Г.К. Советское семейное право : учебник. Москва : Юрид. лит., 1985. 208 с. 
29. Ревуцкая И.Э. Зарегистрированное партнерство как основание создания семьи в законодательстве стран-членов Европейского Союза. Журнал “Legea si Viata” Respublica Moldova. 2017. № 9 (309). C. 102-105.

30. Ревуцька I.Е. «Інші» підстави створення сім'ї. Visegrad Journal on Human Rights. 2017. P. 1. № 1. C. 97-100.

31. Ревуцька І.Е., Булеца С.Б. «Інші» підстави створення сім’ї. Науковий вісник Херсонського держ. ун-ту. 2016. Випуск 6. Т. 1. С. 118-120.

32. Розпорядження Кабінету Міністрів України від 23.11.2015 № 1393-р. «Про затвердження плану дій з реалізації Національної стратегії у сфері прав людини на період до 2020 року». URL: http://www.kmu.gov.ua/ control/uk/cardnpd?docid=248740679 (дата звернення: 17.12.2019).

33. Ромовська 3.В. Україна творить європейське сімейне право. Право України. 2013. № 10. С. 9-29.

34. Старчук О.В. До питання посвідчення нотаріусом конкубінатного договору. Право і суспільство. 2017. № 1. С. 77-81

35. Указ Президента України від 25.08.2015 № 501/2015 «Про затвердження Національної стратегії у сфері прав людини». URL: http://www.president.gov.ua/documents/5012015-19364 (дата звернення: 15.12.2019).

36. Чешир Д. Международное частное право. Москва: Прогресс, $1982.496 \mathrm{c}$.

37. Явор О.А. Адаптація сімейного права України до стандартів європейського правового простору: значення для теорії юридичних фактів. Науковий вісник Ужгородського наи. ун-ту. Серія «Право». 2015. Випуск 4, т. 1. С. 134-137.

Information about the authors:

Buletsa S. B.,

Dr. Sc. (Jur.), Professor, Head of the Department of Civil Law and Procedure of the Faculty of Law SHEI "Uzhhorod National University" Narodna Square, 3, Uzhhorod, Ukraine

Revutska I. E., Cand. Sc. (Jur.), Associate Professor at the Department of Civil Law and Procedure of the Faculty of Law SHEI "Uzhhorod National University" Narodna Square, 3, Uzhhorod, Ukraine

DOI https://doi.org/10.30525/978-9934-588-43-3/1.27 